\title{
Pengaruh Budaya Kerja, Komitmen Pegawai dan Dukungan Organisasi Terhadap Produktifitas Kerja Pegawai Biro Administrasi Sekeretariat Daerah Provinsi DKI Jakarta
}

\author{
Zaman Zaini $^{1, *}$, Mughni Hakim ${ }^{2}$, Hasim A.Abdullah ${ }^{3}$ \\ ${ }^{1}$ Institut Ilmu Sosial dan Manajemen STIAMI, Jakarta, Indonesia \\ ${ }^{2,3}$ Institut Ilmu Sosial dan Manajemen STIAMI, Jakarta, Indonesia \\ ${ }^{1}$ zamanzaini@yahoo.co.id*; ${ }^{2}$ mughni@gmail.com; ${ }^{3}$ hasim0602@gmail.com \\ * corresponding author
}

\section{ARTICLE INFO}

\section{Article historv}

Received 2019-11-15

Revised 2019-12-02

Accepted 2019-12-18

\section{Keywords}

Work Culture,

Employee Commitment,

Organizational Support,

Work Productivity

\section{ABSTRACT}

The problem that is often faced by organizations in achieving their goals is the low productivity of their employees. The problem about work productivity is a common problem that occurs in every organization. Work productivity shows the level of ability of employees to achieve results (ouput), especially in terms of quantity, therefore the level of productivity of each employee can be different.

This study aims to analyze the influence of work culture, employee commitment and organizational support, both partially and simultaneously, on the work productivity of employees of the DKI Jakarta Provincial Secretariat. This research was conducted by questionnaire survey method which was distributed to 67 respondents who were employees of the Regional Secretariat of DKI Jakarta Province. The number of samples in this study were 67 people with the sampling technique used was total sampling. The analysis used in this study is correlation and regression, $t$ test, $F$ test and test coefficient of determination.

The results of the study prove that organizational culture and commitment of employees have a strong influence on employee work productivity, while organizational support has a moderate effect on employee work productivity. Taken together, the three independent variables have a very strong influence on the work productivity of employees of the DKI Jakarta Provincial Secretariat Administration Bureau. The results of the analysis show that these three variables are very dominant factors that influence employee work productivity.

\section{PENDAHULUAN}

Masalah yang sering dihadapi organisasi dalam mencapai tujuan adalah rendahnya produktifitas kerja pegawainya. Produktivitas kerja menunjukkan tingkat kemampuan pegawai dalam mencapai hasil (ouput), terutama dilihat dari sisi kuantitasnya oleh karena itu tingkat produktivitas setiap pegawai bisa berbeda.Peningkatan produktivitas kerja hanya mungkin dilakukan oleh pegawai. Oleh karena itu pegawai merupakan faktor penting dalam mengukur produktivitas kerjanya. Namun kenyataannya, penurunan produktivitas kerja pegawai dalam suatu organisasi masih sering terjadi. Permasalahan tentang produktivitas kerja ini merupakan permasalahan umum yang terjadi pada setiap organisasi. Mangkuprawira (2007:155) menyebutkan ada beberapa faktor yang mempengaruhi produktifitas kerja pegawai, di antaranya budaya kerja dan komitmen pegawai.

Budaya kerja penting dalam pencapaian tujuan organisasi karena merupakan suatu cara kerja yang bermutu dan didasari oleh nilai yang penuh makna, memberikan motivasi dan inspirasi untuk bekerja lebih baik yang diperlihatkan dalam bentuk kerja sungguh-sungguh dan penuh tanggung jawab serta memiliki komitmen untuk menghasilkan pekerjaan yang produktif. Budaya kerja yang kuat akan berpengaruh positif pada perilaku kerja karena dapat mendorong pegawai untuk mencapai produktifitas kerja yang maksimal. Budaya kerja yang kuat juga sangat berpengaruh dalam meningkatkan konsistensi seseorang dalam berperilaku. Dengan kata lain, budaya kerja menjadi faktor penting meningkatkan produktifitas kerja seseorang dalam organisasi.

Faris (2014) mengemukakan bahwa kualitas sumber daya manusia Indonesia tidak mampu bersaing dengan sumber daya manusia dari negara-negara lain, hal ini disebabkan oleh karena faktor budaya kerja yang juga masih lemah dan tidak merata. Ada anggapan bahwa budaya kerja produktif di Indonesia belum 
menjadi kebutuhan karena bekerja masih dianggap sebagai sesuatu yang rutin. Bahkan di sebagian pegawai, bisa jadi bekerja dianggap sebagai beban dan paksaan terutama bagi orang yang malas.

Fenomena lemahnya budaya kerja pegawai yang sering terjadi pada banyak organisasi yaitu tidak terselesaikannya suatu pekerjaan, tidak ditepatinya penyelesaian pekerjaan, anggaran yang berlebihan dan kegiatan lain yang menyimpang dari rencana. Berdasarkan data, lemahnya budaya kerja pegawai Biro Administrasi Sekretariat Daerah Provinsi DKI Jakarta juga menunjukkan hasil yang kurang optimal seperti tampak pada tabel berikut ini :

Tabel 1.1Pencapaian Penyelesaian Pekerjaan

\begin{tabular}{|l|c|l|l|}
\hline Tahun & $\begin{array}{c}\text { Target } \\
\text { Penyelesaian } \\
\text { Pekerjaan }\end{array}$ & Realisasi & Pencapaian \\
\hline 2018 & 73 & 61 & $83,6 \%$ \\
\hline
\end{tabular}

Sumber : Biro Administrasi Setda Prov. DKI Jakarta, data diolah penulis, 2018

Adapun pola budaya kerja yang kurang sehat dapat dilihat aktivitas sehari-hari pegawai tidak kreatif, kurang inovatif dan tidak memiliki wawasan global. Hal ini juga terlihat pada sebagian pegawai Biro Administrasi Sekretariat Daerah Setda Provinsi DKI Jakarta.Upaya untuk mengubah budaya kerja yang lemah sebenarnya sudah dilakukan oleh pimpinan Biro Administrasi Sekretariat Daerah Setda Provinsi DKI Jakarta dengan menerapkan program budaya kerja aparatur dengan maksud meningkatkan produktifitas kerjanya, namun memang dirasakan belum bisa optimal.

Bertitik tolak dari hal tersebut, maka dalam mewujudkan organisasi yang memiliki pegawai dengan tingkat produktifitas kerja tinggi dari aspek budaya kerja, diperlukan komitmen tinggi sebagai hal penting yang menjadi prasyarat.Pegawai yang memiliki komitmen tinggi akan bertanggung jawab dan bersedia memberikan seluruh kemampuan yang dimilikinya karena merasa memiliki organisasi. Rasa memiliki yang kuat akan membuat pegawai merasa berguna dan nyaman berada dalam suatu organisasi, sehingga produktivitas kerjanya semakin baik dan optimal.

Pimpinan dapat menciptakan pegawai yang memiliki komitmen tinggi, salah satu cara yang dapat dilakukan adalah dengan menerapkan pemberian motivasi berupa penghargaan bagi pegawai yang memiliki produktifitas kerja tinggi secara obyektif.Berdasarkan pengamatan penulis, adanya sikap kurang obyektif pimpinan dalam pemberian penghargaan kepada pegawai yang berprestasi berdampak pada menurunnya komitmen pegawai. Ketidakpuasan pegawai terhadap bentuk motivasi yang tidak tepat akan menurunkan minat kerja pegawai, kurangnya kerjasama dengan pegawai sehingga tercipta lingkungan kerja yang kurang kondusif.

Faktor lain yang juga berpengaruh terhadap produktifitas kerja pegawai adalah adanya dukungan organisasi.Jika tidak adanya dukungan yang kuat dari organisasi, karyawan melihat pekerjaan dan tugastugas sebagai sesuatu yang tidak menyenangkan dan memperlihatkan hasil kerja yang tidak produktif untuk organisasi. Suatu penilaian prestasi kerja akan tergolong objektif apabila semua faktor yang ada dimasukkan dalam pertimbangan penilaian, namun hal ini belum terlaksana dengan baik.

Adapun yang menjadi tujuan dari penelitian ini adalah :

a. Mengetahui seberapa besar pengaruh pengaruh budaya kerja terhadap produktifitas kerja pegawai Biro Administrasi Sekretariat Daerah Setda Provinsi DKI Jakarta.

b. Mengetahui seberapa besar pengaruh komitmen pegawai terhadap produktifitas kerja pegawai Biro Administrasi Sekretariat Daerah Setda Provinsi DKI Jakarta.

c. Mengetahui seberapa besar pengaruh dukungan organisasi terhadap produktifitas kerja pegawai Biro Administrasi Sekretariat Daerah Setda Provinsi DKI Jakarta.

d. Mengetahui seberapa besar pengaruh budaya kerja, komitmen pegawai dan dukungan organisasi secara bersama-sama terhadap produktifitas kerja pegawai Biro Administrasi Sekretariat Daerah Setda Provinsi DKI Jakarta.

Penelitian ini dilaksanakan mulai bulan Juli - November 2018. Hasil penelitian ini diharapkan dapat diketahui pentingnya penerapan budaya kerja yang kuat, peningkatan komitmen pegawai dan dukungan organisasi untuk meningkatkan produktifitas kerja pegawai, menjadi sebuah masukan kepada Biro Administrasi Sekretariat Daerah Setda Provinsi DKI Jakarta untuk mengevaluasi kembali budaya kerja dan komitmen setiap pegawai serta dukungan organisasi yang maksimal agar dapat tercipta kondisi dan lingkungan kerja yang kondusif dalam upaya meningkatkan produktifitas kerja seluruh pegawainya dan dapat digunakan sebagai salah satu bahan masukan untuk setiap pegawai Biro Administrasi Sekretariat 
Daerah Setda Provinsi DKI Jakarta untuk terus menjaga budaya kerja dan komitmen yang tinggi dan sehingga dapat memberikan kontribusi produktifitas kerja yang tinggi untuk organisasi

\section{KERANGKA PEMIKIRAN DAN MODEL PENELITIAN}

Budaya kerja yang kuat diyakini dapat menjadi andalan peningkatan produktifitas kerja pegawai. Apabila budaya kerja tersebut berjalan dengan baik maka akan mendorong tingginya produktifitas kerja karyawan (Susanto (2000). Jadi dapat dikatakan bahwa pengaruh budaya kerja sangat kuat dalam meningkatkan produktifitas kerja karyawan yang diharapkan perusahaan.

Meyer dan Allen (1997) menyatakan bahwa pegawai yang memiliki komitmen tinggi akan bekerja dengan penuh dedikasi karena menganggap bahwa hal yang penting yang harus dicapai adalah pencapaian tugas dalam organisasi. Pegawai yang memiliki komitmen yang tinggi juga memiliki pandangan yang positif dan akan melakukan kinerja yang terbaik untuk kepentingan organisasi.

Susskind et al., (2000) berpendapat bahwa dukungan organisasi dapat digunakan untuk meningkatkan motivasi pegawai untuk bekerja sungguh-sungguh, sehingga dapat dikatakan dukungan organisasi dapat berpengaruh positif pada produktifitas kerja pegawai.Robbins (2009: 65) menyatakan bahwa dukungan organisasional yang dirasakan adalah tingkat sampai dimana karyawan yakin organisasi menghargai kontribusi mereka dan peduli dengan kebutuhan mereka. ini :

Dari kerangka pemikiran di atas dapat dibuat konsep penelitianseperti terlihat pada gambar di bawah

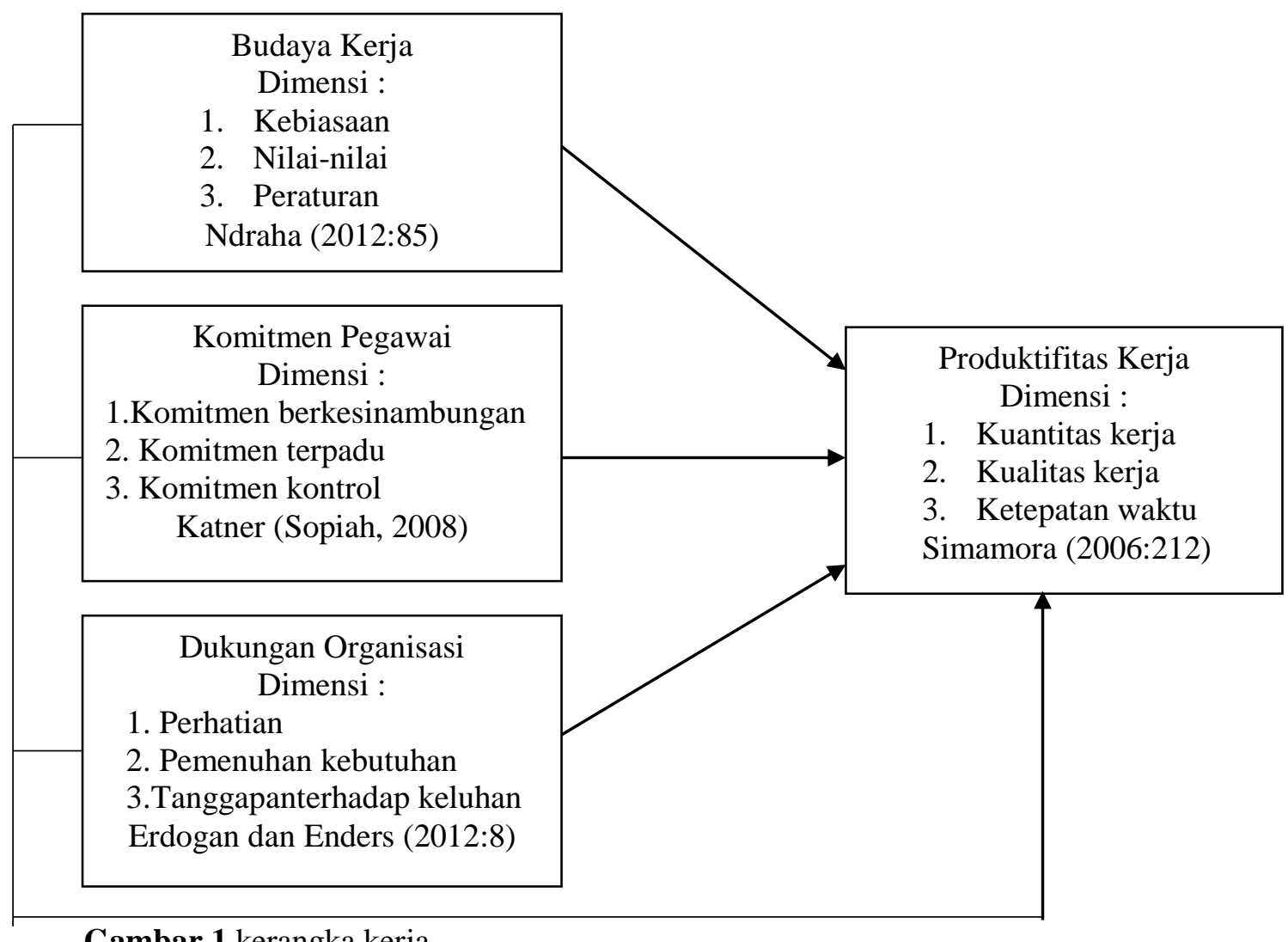

Gambar 1 kerangka kerja

Dari konsep penelitian di atas, penulis mengajukan hipotesis sebagai berikut :

a. Budaya kerja berpengaruh positif dan signifikan terhadapproduktifitas kerja pegawai Biro Administrasi Sekretariat Daerah Setda Provinsi DKI Jakarta.

b. Komitmen pegawai berpengaruh positif dan signifikan terhadap produktifitas kerja pegawai Biro Administrasi Sekretariat Daerah Setda Provinsi DKI Jakarta.

c. Dukungan Organisasi berpengaruh positif dan signifikan terhadapproduktifitas kerja pegawai Biro Administrasi Sekretariat Daerah Setda Provinsi DKI Jakarta. 
d. Budaya kerja, komitmen pegawai dan dukungan organisasi secara bersama-sama berpengaruh positif dan signifikan terhadapproduktifitas kerja pegawai Biro Administrasi Sekretariat Daerah Setda Provinsi DKI Jakarta.

\section{METODE PENELITIAN}

Pendekatan penelitian ini adalah kuantitatif kausalitas karena penelitian ini bertujuan untuk menguji hipotesis yang telah diajukan. Terkait dengan hal tersebut, jenis penelitian ini dikembangkan dalam pendekatan eksplanatif yaitu menjelaskan hubungan dan pengaruh dari beberapa variabel penelitian, sehingga hasil penelitiannya dapat menjelaskan adakah pengaruh variabel bebas secara positif dan signifikan terhadap variabel terikat, baik secara parsial maupun simultan.

Dalam penelitian ini, kuesioner merupakan data primer, sedangkan data sekunder diperoleh dari jurnal-jurnal dan sumber-sumber lain yang dapat dijadikan bahan masukan untuk mendukung penelitian. Data primer dikumpulkan melalui pembagian kuesioner yang berisi pernyataan tertutup kepada responden penelitian. Jawaban responden atas kuesioner diberikan ranking dengan menggunakan skala likert. Adapun populasi dan sampel dalam penelitian ini adalah pegawai Biro Administras Sekretariat Daerah Provinsi DKI Jakarta.Teknik pengambilan sampel yang digunakan dalam penelitian ini adalah totalsampling.

Teknik pengumpulan data yang digunakan dalam penelitian ini adalah melalui pembagian angket dan observasi. Angketdilakukan dengan jalan memberikan pernyataan kepada para responden. Pengumpulan data penelitian dengan kuisioner ini bertujuan untuk memperoleh data berupa tanggapan responden terhadap variabel-variabel penelitian.Sementara observasi dilakukan dengan mengamati obyek-obyek penelitian secara langsung sehingga mendapatkan masukan untuk menyempurnakan penelitian.

Langkah selanjutnya adalah melakukan pengujian terhadap kualitas data, dengan uji validitas dan reliabilitas.Validitas menunjukkan sejauh mana suatu alat ukur itu mengukur construct yang akan diukur.Uji validitasini dilakukan dengan menggunakan metode korelasi Product Moment Pearson dengan membandingkan $\mathrm{r}$ hitung dengan $\mathrm{r}$ tabel.Uji reliabilitas merupakan uji kehandalan yang bertujuan untuk mengetahui seberapa jauh sebuah alat ukur dapat diandalkan atau dipercaya. Apabila suatu alat ukur ketika digunakan secara berulang dan hasil pengukuran yang diperoleh relatif konsisten maka alat ukur tersebut dianggap handal dan reliabel. Pengujian reliabilitas terhadap seluruh pertanyaan yang dipergunakan pada penelitian ini akan menggunakan formula cronbach alpha (koefisien alfa cronbach), dimana secara umum yang dianggap reliabel apabila nilai alpha cronbachnya $>0,5$.

Selain uji kualitas instrumen penelitian, dilakukan juga uji asumsi klasik, yang terdiri dari uji normalitas, uji homogenitas dan uji multikolinearitas.Uji normalitas bertujuan untuk mengukur apakah data yang didapatkan memiliki distribusi normal. Dengan kata lain, apakah data yang diperoleh berasal dari populasi yang berdistribusi normal. Dalam penelitian ini, uji normalitas menggunakan KolmogorovSmirnov.Uji homogenitas digunakan untuk mengetahui apakah beberapa varian populasi adalah sama atau tidak. Uji ini dilakukan sebagai prasyarat dalam analisis independent sample $t$ test dan ANOVA. Sebagai kriteria pengujian, jika nilai signifikansi lebih dari 0,05 maka dapat dikatakan bahwa varian dari dua atau lebih kelompok data adalah sama.Uji multikolinearitas digunakan untuk mengetahui ada atau tidaknya penyimpangan asumsi klasik multikolinearitas yaitu adanya hubungan linear antar variabel independen dalam model regresi. Metode pengujian uji multikolinearitas yang digunakan dalam penelitian ini dengan melihat nilai inflation factor (VIF) pada model regresi.Menurut Ghozali (2012:91), "Pada umumnya jika VIF lebih besar dari 10, maka variabel tersebut mempunyai persoalan multikolinearitas dengan variabel bebas lainnya".

Setelah memenuhi persyaratan asumsi klasik, kemudian dilanjutkan dengan analisis korelasi dan regresi. Korelasi adalah teknik statistik yang digunakan untuk meguji ada/tidaknya hubungan serta arah hubungan dari dua variabel atau lebih. Sedangkan analisis regresi adalah untuk menguji sejauh mana pengaruh variabel independen terhadap variabel dependen setelah diketahui ada hubungan antara variabel tersebut.

Untuk menguji apakah hipotesis yang diajukan diterima atau ditolak, maka dilakukan pengujian terhadap variabel-variabel penelitian secara parsial dan bersama-sama. Pengujian secara parsial digunakan uji statistik t. Uji t diperlukan untuk mengetahui tingkat pengaruh variabel bebas terhadap variabel terikat secara pasial. Kriteria pengujian yang digunakan adalah nilai $t_{\text {hitung }}>t_{\text {tabel. }}$ Uji Fdigunakan untuk menguji pengaruh dua variabel bebas atau lebih secara bersama-sama terhadap variabel terikat.Untuk mengukur seberapa besar variabel-variabel bebas dapat menjelaskan variabel terikat, digunakan koefisien determinasi $\left(\mathrm{R}^{2}\right)$. Koefisien ini menunjukkan proporsi variabilitas total pada variabel terikat yang dijelaskan model regresi. Nilai $\mathrm{R}^{2}$ berada pada interval $0 \leq \mathrm{R}^{2} \leq 1$. 


\section{HASIL PENELITIAN DAN PEMBAHASAN}

\section{Gambaran Umum Obyek Penelitian}

Sekretariat Daerah merupakan unsur staf Pemerintah Daerah yang dipimpin oleh Sekretaris Daerah yang berkedudukan di bawah dan bertanggungjawab kepada Gubernur. Sekretariat Daerah mempunyai tugas membantu Gubernur dalam menyusun kebijakan Pemerintahan Daerah dan mengoordinasikan Perangkat Daerah. Sekretariat Daerah mempunyai tugas membantu Gubernur dalam menyusun kebijakan pemerintahan daerah dan mengoordinasikan perangkat daerah. Dalam melaksanakan tugas dan fungsi, Biro Administrasi Sekretariat Daerah mempunyai visi dan misi sebagai berikut :

Visi Biro Administrasi : "Menjadi biro yang dapat mengelola administrasi keuangan dan aset sekretariat daerah ang efisien, efektif, transparan, dan akuntabel."

Misi Biro Administrasi :

a. Mewujudkan peran dan fungsi biro dalam pengelolaan administrasi keuangan dan aset sekretariat daerah

b. Mewujudkan penyusunan laporan keuangan konsolidasi SKPD sekretariat daerah; dan

c. Mewujudkan dan melaksanakan pengelolaan kepegawaian sekretariat daerah.

\section{Karakteristik Responden}

Karakteristik responden berdasarkan jenis kelamin terlihat bahwa responden laki-laki lebih mendominasi dibandingkan perempuan. Jumlah responden laki-laki sebanyak 46 orang $(68,6 \%)$ dan perempuan sebanyak 21 orang $(31,4 \%)$.Berdasarkan pendidikan terakhir yangdimiliki responden terlihat bahwa responden dengan pendidikan terakhirSMA berjumlah 13 orang $(19,4 \%)$, Diploma berjumlah 27 orang $(40,2 \%)$, S1 berjumlah 19 orang $(28,4 \%)$ dan Pascasarjana berjumlah 8 orang $(11,9 \%)$. Berdasarkan usia terlihat bahwa usia responden $<30$ tahun berjumlah 22 orang $(32,8 \%)$, usia usia 31-40 tahun berjumlah 32 responden $(47,8 \%)$, usia 41 - 50 tahun berjumlah 13 orang $(19,4 \%)$.

\section{Deskripsi Data Variabel Penelitian}

Analisis deskriptif ini dimaksudkan untuk mengetahui kondisi masing-masing variabel berdasarkan tanggapan responden yang diperoleh dari kuesioner, selanjutnya dilakukan tabulasi sederhana untuk diberikan interprestasinya. Pengukuran statistik deskriptif variabel dilakukan untuk memberikangambaran umum mengenai kisaran teoritis, kisaran aktual, rata-rata (mean)dan standar deviasi dari masing-masing variabel. Berdasarkan hasil pengolahan data, dapat dideskripsikan bahwa variabel Budaya Kerja $\left(\mathrm{X}_{1}\right)$ memiliki nilai mean 36,60dan standar deviasi 5,797,variabel Komitmen Pegawai $\left(\mathrm{X}_{2}\right)$ memiliki nilai mean 38,37dan standar deviasi5,324, variabel Dukungan Organisasi $\left(\mathrm{X}_{3}\right)$ memiliki nilai mean 35,63 dan standar deviasi 4,836, sedangkan variabel Produktifitas Kerja (Y)memilikinilai mean 37,66dan standar deviasi 4,283.

\section{Uji Kualitas Data}

a. Hasil Uji Validitas

Pengujian ini dilakukan dengan menggunakan Pearson Correlation. Pedoman suatu model bisa dikatakan valid bila tingkat signifikan $>0,05$. Dari hasil pengolahan data, diperoleh nilai $r$ hitung lebih besar dari $r$ tabel, maka dapat disimpulkan bahwa semua pernyataan masing-masing variabel dinyatakan valid.

b. Hasil Uji Reliabilitas

Suatu kuesioner dapat dikatakan reliabel atau handal jika jawaban seorang responden adalah konsisten atau stabil dari waktu ke waktu. Pedoman alat pengukur dikatakan reliabel jika nilai koefisien alpha di atas 0,60 .

\begin{tabular}{|c|c|c|c|}
\hline Variabel & Alpha Hitung & Standar Alpha & Keterangan \\
\hline $\mathrm{X}_{1}$ & 0,842 & 0,60 & Reliabel \\
\hline $\mathrm{X}_{2}$ & 0,862 & 0,60 & Reliabel \\
\hline $\mathrm{X}_{3}$ & 0,900 & 0,60 & Reliabel \\
\hline $\mathrm{Y}$ & 0,892 & 0,60 & Reliabel \\
\hline
\end{tabular}


Berdasarkan hasil uji statistik pada tabel di atas menunjukkan bahwa pernyataan dalam kuesioner ini reliabel karenamempunyai nilai Cronbach's Alpha lebih besar dari 0,60.Hal ini menunjukkan bahwa setiap item pernyataan untuk setiap variabel yangdigunakan akan mampu memperoleh data yang konsisten yang berarti bilapernyataan itu diajukan kembali akan diperoleh jawaban yang relatif samadengan jawaban sebelumnya.

\section{Uji Asumsi Klasik}

a. Hasil Uji Normalitas

Uji normalitas data dalam penelitian ini menggunakan Uji Kolmologorov-Smirnov.

One Sample Kolmogorov-Smirnov Test

\begin{tabular}{|c|c|c|}
\hline & & $\begin{array}{c}\text { Unstandardized } \\
\text { Residual } \\
\end{array}$ \\
\hline \multirow{3}{*}{$\begin{array}{l}\mathrm{N} \\
\text { Normal Parameters }\end{array}$} & & 67 \\
\hline & Mean & .00000000 \\
\hline & Std. & .21219943 \\
\hline Most Extreme & Deviation & 109 \\
\hline \multirow{3}{*}{ Differences } & Absolute & 109 \\
\hline & Positive & \\
\hline & Negatif & .512 \\
\hline \multicolumn{2}{|l|}{ Kolgomorov-Smirnov Z } & .031 \\
\hline
\end{tabular}

Pada tabel di atas terlihat nilai pada kolom Kolmogorov-Smirnov sebesar 0,512, lebih besar dari 0,01, maka dapat disimpulkan bahwa data terdistribusi normal. Setelah dilakukan analisis statistik, maka diperoleh hasil dari normal probability plotmenunjukkan suatu pola yang menggambarkandistribusi normal.Berdasarkan grafik normal plot, titik-titik menyebar di sekitar garis diagonal sertapenyebarannya mengikuti arah garis diagonal sehingga memenuhi asumsinormalitas. Hal ini menunjukkanbahwa model regresi layak dipakai dalam penelitian ini.

\section{Normal P-P Plot of Regression Standardized Residual}

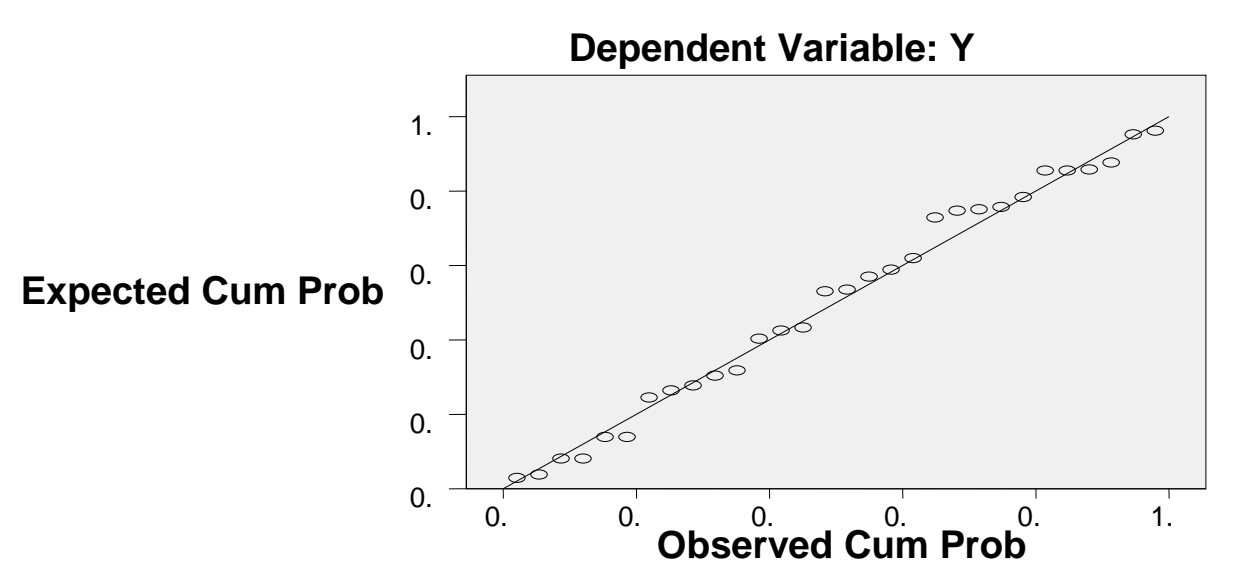

b. Hasil Uji Multikolinearitas

\begin{tabular}{|c|c|c|}
\hline \multirow[t]{2}{*}{ Model } & \multicolumn{2}{|c|}{ Collinearity Statistic } \\
\hline & Tolerance & VIF \\
\hline (Constant) & & \\
\hline Budaya Kerja & .372 & 1.161 \\
\hline Komitmen Pegawai & .372 & 1.161 \\
\hline Dukungan Organisasi & .372 & 1.161 \\
\hline
\end{tabular}


Dari tabel di atas diketahui nilai toleransi kedua variabel adalah 0,372 dan nilai VIF nya kurang dari 10. Maka dapat disimpulkan bahwa tidak terjadi persoalan multikolinieritas antara variabel independen yang satu dengan yang lainnya (Priyatno, 2008: 39).

c. Hasil Uji Heterokedastisitas

Maksud dari penyimpangan heteroskedastisitas adalah variabel independen adalah tidak konstan (berbeda) untuk setiap nilai tertentu variabel independen. Pada modal regresi linier nilai residual tidak boleh ada hubungan dengan variabel bebas. Untuk mendeteksi ada tidaknya heterokedastisitas adalah dengan melihat hasil grafik scatterplot apakah membentuk suatu pola tertentu atau tidak.Hasil uji heterokedastisitas dapat dilihat pada grafik berikut ini :

Dependent Variable :Produktifitas Kerja

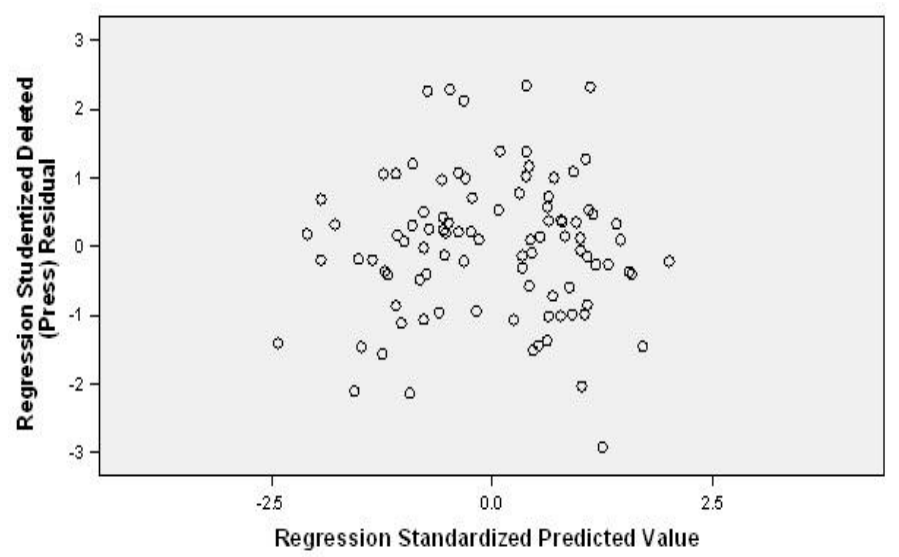

\section{Hasil Analisis Korelasi dan Regresi}

\section{a. Variabel X1 dan Y}

Model Summary

\begin{tabular}{|l|c|c|r|r|}
\hline Model & $\mathrm{R}$ & $\begin{array}{c}\mathrm{R} \\
\text { Squares }\end{array}$ & $\begin{array}{c}\text { Adjusted } \\
\text { R Squares }\end{array}$ & $\begin{array}{c}\text { Std. Error } \\
\text { the estimate }\end{array}$ \\
\hline 1 & $.778^{\mathrm{a}}$ & .605 & .173 & 5.08932 \\
\hline
\end{tabular}

a.Predictors (Constant), X1

b.Dependent Variabel; Y

Berdasarkan tabel di atas dapat dilihat bahwa nilai $\mathrm{R}$ sebesar 0,778. Nilai tersebut jika diinterpretasikan menggambarkan bahwa variabel budaya kerja memiliki hubungan yang kuat dengan produktifitas kerja pegawai berdasarkan interpretasi koefisien korelasi.

\section{Coefficients(a)}

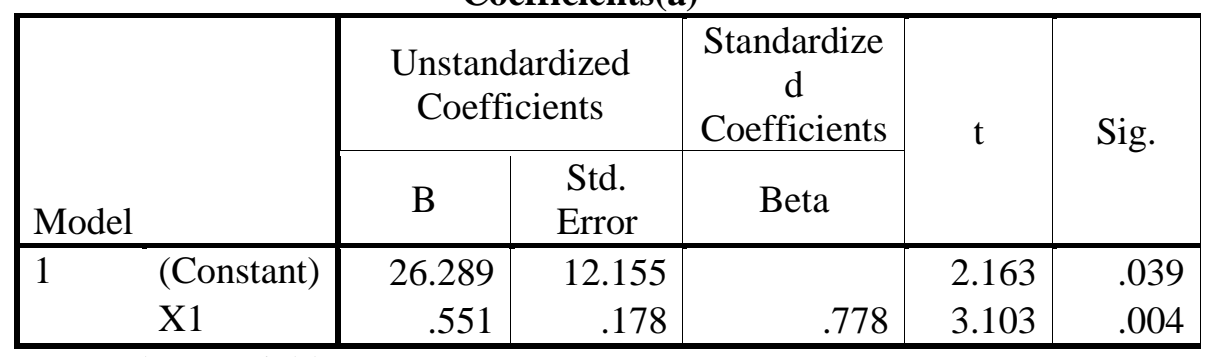

a Dependent Variable: Y

Dari hasil tabel di atas diperoleh nilai koefisien konstanta a sebesar 26,289 dan b sebesar 0,551. Dengan demikian dapat dibentuk dalam persamaan regresi $Y=26,289+0,551 \mathrm{X}_{1}$. Hal ini membuktikan bahwa setiap peningkatan satu poin pada variabel $\mathrm{Y}$, maka akan meningkatkan variabel $\mathrm{X}_{1}$ sebesar 0,551 pada konstanta 26,289. 


\section{b. Variabel X2 dan Y}

\begin{tabular}{|l|c|r|r|r|}
\hline \multicolumn{1}{|c|}{ Model } & $\mathrm{R}$ & $\begin{array}{c}\mathrm{R} \\
\text { Square } \\
\mathrm{s}\end{array}$ & $\begin{array}{c}\text { Adjusted } \\
\text { R Squares }\end{array}$ & $\begin{array}{c}\text { Std. Error } \\
\text { The estimate }\end{array}$ \\
\hline 1 & $\begin{array}{c}.869 \\
\mathrm{a}\end{array}$ & .756 & .113 & 5.27982 \\
\hline
\end{tabular}

a. Predictors; Constans : $\mathrm{X}_{2}$

b. Dependent Variable : Y

Berdasarkan hasil tabel di atas diperoleh nilai $\mathrm{R}$ sebesar 0,869. Nilai tersebut jika diinterpretasikan menggambarkan bahwa variabel komitmen pegawai memiliki hubungan yang sangat kuat dengan produktifitas kerja pegawai berdasarkan interpretasi koefisien korelasi.

\section{Coefficients(a)}

\begin{tabular}{|c|c|c|c|c|c|c|}
\hline \multirow{2}{*}{\multicolumn{2}{|c|}{ Model }} & \multicolumn{2}{|c|}{$\begin{array}{l}\text { Unstandardized } \\
\text { Coefficients }\end{array}$} & \multirow{2}{*}{$\begin{array}{c}\begin{array}{c}\text { Standardize } \\
\mathrm{d} \\
\text { Coefficients }\end{array} \\
\text { Beta }\end{array}$} & \multirow{2}{*}{$\mathrm{t}$} & \multirow{2}{*}{ Sig. } \\
\hline & & B & $\begin{array}{l}\text { Std. } \\
\text { Error }\end{array}$ & & & \\
\hline & (Constant) & 27.894 & 13.677 & & 2.163 & .051 \\
\hline & $\mathrm{X} 2$ & .535 & .203 & .869 & 2.691 & .013 \\
\hline
\end{tabular}

a Dependent Variable: Y

Dari hasil tabel di atas diperoleh nilai koefisien konstanta a sebesar 27,894 dan b sebesar 0,535. Dengan demikian dapat dibentuk dalam persamaan regresi $\mathrm{Y}=27,894+0,535 \mathrm{X}_{2}$. Hal ini membuktikan bahwa setiap peningkatan satu poin pada variabel $\mathrm{Y}$, maka akan meningkatkan variabel $\mathrm{X}_{2}$ sebesar 0,535 pada konstanta 27,894 .

\section{c. Variabel X3 dan Y}

\begin{tabular}{|l|c|c|r|r|}
\hline \multicolumn{1}{|c|}{ Model } & $\mathrm{R}$ & $\begin{array}{c}\mathrm{R} \\
\text { Square } \\
\mathrm{s}\end{array}$ & $\begin{array}{c}\text { Adjusted } \\
\text { R Squares }\end{array}$ & $\begin{array}{c}\text { Std. Error } \\
\text { The estimate }\end{array}$ \\
\hline 1 & $\begin{array}{c}.678 \\
\mathrm{a}\end{array}$ & .459 & .219 & 4.81460 \\
\hline
\end{tabular}

a. Predictors; Constans : $\mathrm{X}_{3}$

b. Dependent Variable : Y

Berdasarkan hasil tabel di atas diperoleh nilai $\mathrm{R}$ sebesar 0,678. Nilai tersebut jika diinterpretasikan variabel dukungan organisasi memiliki hubungan yang kuat dengan produktifitas kerja pegawai berdasarkan interpretasi koefisien korelasi.

Coefficients(a)

\begin{tabular}{|c|c|c|c|c|c|c|}
\hline \multirow{2}{*}{\multicolumn{2}{|c|}{ Model }} & \multicolumn{2}{|c|}{$\begin{array}{l}\text { Unstandardized } \\
\text { Coefficients }\end{array}$} & \multirow{2}{*}{\begin{tabular}{|c|}
$\begin{array}{c}\text { Standardize } \\
\mathrm{d}\end{array}$ \\
Coefficients
\end{tabular}} & \multirow{2}{*}{$\mathrm{t}$} & \multirow{2}{*}{ Sig. } \\
\hline & & B & $\begin{array}{l}\text { Std. } \\
\text { Error }\end{array}$ & & & \\
\hline$\overline{1}$ & $\begin{array}{l}\text { (Constant) } \\
\text { X3 }\end{array}$ & $\begin{array}{r}29.112 \\
.435\end{array}$ & $\begin{array}{r}12.901 \\
.106\end{array}$ & 678 & $\begin{array}{l}2.312 \\
2.639\end{array}$ & $\begin{array}{l}.009 \\
.002\end{array}$ \\
\hline
\end{tabular}

a Dependent Variable: Y 
Dari hasil tabel di atas diperoleh nilai koefisien konstanta a sebesar 29,112 dan b sebesar 0,435. Dengan demikian dapat dibentuk dalam persamaan regresi $\mathrm{Y}=29,112+0,435 \mathrm{X}_{3}$. Hal ini membuktikan bahwa setiap peningkatan satu poin pada variabel $\mathrm{Y}$, maka akan meningkatkan variabel $\mathrm{X}_{3}$ sebesar 0,435 pada konstanta 29,112.

\section{d. Variabel X1, X2, X3 dan Y}

\begin{tabular}{|l|c|r|r|r|}
\hline \multicolumn{5}{|c}{ Model Summary } \\
Model & R & R Square & $\begin{array}{c}\text { Adjusted } \\
\text { R Square }\end{array}$ & $\begin{array}{r}\text { Std. Error of } \\
\text { the Estimate }\end{array}$ \\
\hline 1 & $.941(\mathrm{a})$ & .886 & .055 & 2.065 \\
\hline
\end{tabular}

a Predictors: (Constant), $\mathrm{X}_{1}, \mathrm{X}_{2}, \mathrm{X}_{3}$

b Dependent Variable: $Y$

Berdasarkan hasil tabel $\mathrm{di}$ atas diperoleh nilai $\mathrm{R}$ sebesar 0,941. Nilai tersebut jika diinterpretasikan ketiga variabel bebas memiliki hubungan yang sangat kuat dengan variabel terikat berdasarkan interpretasi koefisien korelasi.

\section{Coefficients (a)}

\begin{tabular}{|c|c|c|c|c|c|}
\hline \multirow[t]{2}{*}{ Model } & \multicolumn{2}{|c|}{$\begin{array}{l}\text { Unstandardized } \\
\text { Coefficients }\end{array}$} & \multirow{2}{*}{$\begin{array}{c}\begin{array}{c}\text { Standardized } \\
\text { Coefficients }\end{array} \\
\text { Beta }\end{array}$} & \multirow[b]{2}{*}{$\mathrm{t}$} & \multirow[b]{2}{*}{ Sig. } \\
\hline & B & $\begin{array}{l}\text { Std. } \\
\text { Error }\end{array}$ & & & \\
\hline 1 (Constant) & 17.895 & 14.714 & & 5.157 & .000 \\
\hline $\mathrm{X}_{1}$ & .405 & .219 & .778 & 3.103 & .004 \\
\hline $\mathrm{X}_{2}$ & .271 & .241 & .869 & 2.691 & .013 \\
\hline $\mathrm{X}_{3}$ & .137 & .151 & .678 & 2.639 & .002 \\
\hline
\end{tabular}

a. Dependent Variable: $\mathrm{Y}$

Hasil analisis data diperoleh persamaan regresi berganda sebagai berikut : $\hat{Y}=17,895+0,405$ $\mathrm{X}_{1}+0,271 \mathrm{X}_{2}+0,1378 \mathrm{X}_{3}$. Dari hasil tersebut dapat diinterpretasikan sebagai berikut :

- Setiap peningkatansatu skor variabel X1 akan meningkatkan 0,405 skor variabel Y dengan asumsi variabel X2 dan X3 tetap/tidak berubah.

- Setiap peningkatan satu skor variabel X2 akan meningkatkan 0,271 skor variabel Y, dengan asumsi variabel X1 dan X3 tetap/tidak berubah.

- Setiap peningkatan satu skor variabel X3 akan meningkatkan 0,137 skor variabel Y, dengan asumsi variabel X1 dan X3 tetap/tidak berubah.

\section{Hasil Uji Hipotesis}

\section{a. Uji t}

1) Hasil uji t untuk Hipotesis pertama

Berdasarkan hasil analisis statistik menggunakan program statistik SPSS terbukti bahwa budaya kerja berpengaruh positif dan signifikan terhadap produktifitas kerja pegawai Biro Administrasi Sekretariat Daerah Provinsi DKI Jakarta. Hal ini dibuktikan dengan thitung $(3,103)$ $>$ ttabel $(2,105)$ dan nilai signifikan $(0,004)<0,05$, oleh karena itu hasil uji hipotesis pertama layak dijadikan hasil akhir atau rujuan untuk penelitian selanjutnya..

Budaya kerja yang kuat diyakini dapat menjadi andalan peningkatan produktifitas kerja pegawai. Apabila budaya kerja tersebut berjalan dengan baik maka akan mendorong tingginya produktifitas kerja karyawan (Susanto (2000). Brown dan Dennis (Nugroho, 2011) juga menyatakan bahwa budaya kerja mempengaruhi organisasi dalam berbagai cara, artinya dengan penerimaan yang kuat terhadap budaya kerja, maka akan berpengaruh terhadap produktifitas kerja karyawan.

Kedua variabel pun memiliki hubungan, dilihat dari nilai $\mathrm{r}_{\text {hitung }}$ sebesar 0,778 dan dapat dikategorikan mempunyai hubungan yang kuat. Persamaan regresi yang terbentuk dari kedua variabel tersebut adalah $\mathrm{Y}=26,289+0,551 \mathrm{X}_{1}$. Untuk koefisien determinasi berdasarkan $\mathrm{R}^{2}$, didapat nilai 0,605 . Nilai tersebut jika dipresentasikan sebesar $60,5 \%$. Dengan kata lain pengaruh budaya 
kerja terhadap produktifitas kerja pegawai sebesar $60,5 \%$, sedang sisanya sebesar 39,5\% dipengaruhi oleh variabel lain yang tidak dianalisis dalam penelitian ini.

Dari hasil analisis dapat disimpulkan bahwa semakin kuat penerimaan dan penerapan budaya kerja dalam suatu organisasi maka akan meningkatkan produktifitas kerja seluruh karyawan dalam organisasi tersebut.

2) Hasil uji t untuk hipotesis kedua

Seperti halnya uji hipotesis sebelumnya, telah terbukti bahwa komitmen pegawai berpengaruh positif dan signifikan terhadap produktifitas kerja pegawai Biro Administrasi Sekretariat Daerah Provinsi DKI Jakarta. Hal ini dibuktikan dari thitung $(2,691)$ lebih besar dari ttabel $(2,105)$,dan nilai signifikansi $(0,013)<0,05$, oleh karena itu hasil uji hipotesis kedua layak dijadikan hasil akhir atau rujuan untuk penelitian selanjutnya.

Meyer dan Allen (1997) menyatakan bahwa pegawai yang memiliki komitmen tinggi akan bekerja dengan penuh dedikasi karena menganggap bahwa hal yang penting yang harus dicapai adalah pencapaian tugas dalam organisasi. Pegawai yang memiliki komitmen yang tinggi juga memiliki pandangan yang positif dan akan melakukan kinerja yang terbaik untuk kepentingan organisasi.

Kedua variabel pun memiliki hubungan, dilihat dari nilai rhitung sebesar 0,869 dan dapat dikategorikan mempunyai hubungan yang kuat. Persamaan regresi yang terbentuk dari kedua variabel tersebut adalah $\mathrm{Y}=27,894+0,535 \mathrm{X} 2$. Untuk hasil koefisien determinasi dari kedua variabel tersebut diperoleh nilai $\mathrm{R} 2=0,756$. Nilai tersebut jika dipresentasikan sebesar $75,6 \%$, dengan kata lain pengaruh komitmen pegawai terhadap produktifitas kerja pegawai sebesar $75,6 \%$, sedang sisanya sebesar 24,4\% dipengaruhi oleh variabel lain yang tidak dianalisis dalam penelitian ini.

Dari hasil analisis di atas, dapat disimpulkan bahwa semakin tinggi komitmen yang dimiliki oleh setiap pegawai maka akan meningkatkan produktifitas kerjanya..

3) Hasil uji t untuk hipotesis ketiga

Seperti uji dua hipotesis sebelumnya, telah terbukti bahwa dukungan organisasi berpengaruh positif dan signifikan terhadap produktifitas kerja pegawai Biro Administrasi Sekretariat Daerah Provinsi DKI Jakarta. Hal ini dibuktikan dari t hitung $(2,639)$ lebih besar dari t tabel $(2,105)$, dan nilai signifikansi $(0,002)<0,05$, oleh karena itu hasil uji hipotesis ketiga layak dijadikan hasil akhir atau rujuan untuk penelitian selanjutnya.

Salah satu elemen yang mempengaruhi perilaku karyawan itu sendiri adalah dukungan organisasi yang melingkupinya. Dukungan positif dari pimpinan dan segenap karyawan akan menciptakan situasi kerja yang kondusif. Dengan mendapatkan dukungan tersebut produktifitas kerja karyawan akan terpacu untuk lebih baik. Susskind et al., (2000) juga berpendapat bahwa dukungan organisasi dapat digunakan untuk meningkatkan motivasi pegawai untuk bekerja sungguh-sungguh.

Kedua variabel pun memiliki hubungan, dilihat dari nilai rhitung sebesar 0,678 dan dapat dikategorikan mempunyai hubungan yang kuat. Persamaan regresi yang terbentuk dari kedua variabel tersebut adalah $\mathrm{Y}=29,112+0,435 \mathrm{X} 3$. Untuk hasil koefisien determinasi dari kedua variabel tersebut diperoleh nilai $\mathrm{R} 2=0,459$. Nilai tersebut jika dipresentasikan sebesar $45,9 \%$, dengan kata lain pengaruh dukungan organisasi terhadap produktifitas kerja pegawai sebesar $45,9 \%$, sedang sisanya sebesar 54,1\% dipengaruhi oleh variabel lain yang tidak dianalisis dalam penelitian ini.

Dari hasil analisis di atas, dapat disimpulkan bahwa semakin lengkap dan memadai dukungan yang diberikan oleh organisasi maka akan memacu pegawai untuk meningkatkan produktifitas kerjanya.

\section{b. Uji F}

Anova $^{\mathbf{b}}$

\begin{tabular}{|l|r|r|r|r|r|}
\hline Model & $\begin{array}{c}\text { Sum of } \\
\text { Squares }\end{array}$ & \multicolumn{1}{c|}{ df } & $\begin{array}{c}\text { Mean } \\
\text { Square }\end{array}$ & F & Sig. \\
\hline 1 & 281.903 & 3 & 140.951 & 5.493 & $.010^{\mathrm{a}}$ \\
$\begin{array}{c}\text { Regression } \\
\text { Residual } \\
\quad \text { Total }\end{array}$ & 992.797 & 56 & 25.659 & & \\
$\quad 974.700$ & 59 & & & \\
\hline
\end{tabular}

a. Predictors (Constant), X1, X2,X3

b. Dependent Variable: Y 
Berbeda dengan tigauji hipotesis sebelumnya, kali ini digunakan analisis regresi berganda yang menunjukkan bahwa budaya kerja, komitmen pegawai dan dukungan organisasi secara bersamasamaberpengaruh positif dan signifikan terhadap produktifitas kerja pegawai Biro Administrasi Sekretariat Daerah Provinsi DKI Jakarta. Keputusan ini diperoleh karena nilai $\mathrm{F}_{\text {hitung }}(5,493)$ lebih besar dari $\mathrm{F}_{\text {tabel }}(3,04)$,oleh karena itu hasil uji hipotesis keempat layak dijadikan hasil akhir atau rujuan untuk penelitian selanjutnya.

Ketiga variabel bebas dan satu variabel terikat tersebut memiliki hubungan, dilihat dari nilai $\mathrm{r}_{\text {hitung }}$ sebesar 0,941 dan dapat dikategorikan mempunyai hubungan yang sangat kuat. Persamaan regresi yang terbentuk dari keempat variabel tersebut adalahY $=17,895+0,405 \mathrm{X}_{1}+0,271 \mathrm{X}_{2}+0,137$ $\mathrm{X}_{3}$.Sedangkan untuk koefisien determinasi dari ketiga variabel tersebut, diperoleh nilai $\mathrm{R}^{2}=0,886$. Nilai tersebut jika dipresentasikan sebesar $88,6 \%$, dengan kata lain pengaruh dari variabel $\mathrm{X}_{1}, \mathrm{X}_{2}$ dan $\mathrm{X}_{3}$ terhadap Y secara bersama-sama sebesar $88,6 \%$ sedangkan sisanya 11,4\% dipengaruhi oleh faktor lain yang tidak dianalisis dalam penelitian ini. Dari hasil ini, terbukti bahwa budaya kerja, komitmen pegawai dan dukungan organisasi merupakan faktor yang sangat dominan meningkatkan produktifitas kerja pegawai.

\section{KESIMPULAN DAN SARAN}

Dari hasil uji hipotesis, terbukti bahwa semua hipotesis yang diajukan diterima. Hasil penelitian membuktikan bahwa budaya organisasi dan komitmen pegawai berpengaruh kuat terhadap produktifitas kerja pegawai, sedangkan dukungan organisasi berpengaruh sedang terhadap produktifitas kerja pegawai. Secara bersama-sama, ketiga variabel bebas tersebut berpengaruh sangat kuat terhadap produktifitas kerja pegawai Biro Administrasi Sekretariat Daerah Provinsi DKI Jakarta. Hasil analisis menunjukkan bahwa ketiga variabel tersebut merupakan faktor yang sangat dominan mempengaruh produktifitas kerja pegawai.

Untuk itu penulis memberikan saran yang mungkin dapat dilaksanakan oleh pimpinan dan pegawai Biro Administrasi Sekretariat Daerah Provinsi DKI Jakarta untuk meningkatkan produktifitas kerjanya sebagaiberikut :

1. Memberikan perhatian dan arahan kepada bawahan dalam setiap pelaksanaan pekerjaan agar dapat berjalan dengan harapan.

2. Mengharuskan setiap pegawai untuk membuat perencanaan sebelum melaksanakan pekerjaan agar hasil yang diperoleh lebih maksimal.

3. Penegakan disiplin yang ketat terhadap seluruh pegawai agar dapat mengikuti aturan yang telah ditetapkan oleh instansi.

4. Menerapkan sistem reward and punishment yang tepat dan adil.

5. Menciptakan suasana kerja yang kondusif agar komunikasi antara pimpinan dengan bawahan maupun antar rekan kerja terjalin dengan baik.

\section{DAFTAR PUSTAKA}

Allen et al., 2010,Crop Evapotranspiration, FAO Irrigation and Drainage Paper

Alamgir, M., Nasir, T., Shamsuddoha, M., and Nedelea, A., 2011,Influence of Brand Name on Consumer Decision Making Process- an Empirical Study on Car Buyers, The Annals of The "Ştefan cel Mare" University of Suceava, 10(2),pp: 142-153

Arifin, Noor, 2012,Analisis Budaya Organisasional Terhadap Komitmen Kerja Karyawan Dalam Peningkatan Kinerja Organisasional Karyawan Pada Koperasi Bmt Di Kecamatan Jepara, Jurnal Ekonomi \& Pendidikan, Volume 8 Nomor 2,

Creswell, John, 1994, Research Design: Qualitative and Quantitative Approaches, London: SAGE Publications

Danish R. Q., S. Ramzan dan F. Ahmad, 2013, Effect of Perceived Organizational Support and Work Environment on Organizational Commitment; Mediating Role of Self-Monitoring, Advances in Economics and Business, Vol. 1 (4)

Darmadi, Wayan Gede, 2006,Kepemimpinan Partisipasif Terhadap Produktivitas Kerja Karyawan. Yogyakarta: Fakultas ekonomi universitas Janabadra 
Dedi, Kurniawan, dkk., 2012,Pengaruh Budaya Kerja Dan Motivasi Kerja Terhadap Kinerja Karyawan International Federation Red Cross (IFRC) Banda Aceh, Jurnal Ilmu Manajemen, Pascasarjana Universitas Syiah Kuala, 1(1/1) 2012; hal 1- 16

Dessler, Gary,2010, Human Resources Management, Jakarta, Erlangga

Ellyana, Sari, 2005,Budaya Organisasi (Membangun Etos Kerja Profesional), Jakarta, Jayabaya University Press

Eisenberger, R., 2010, Perceived Organizational Support: a Review of the Literature, Journal of Applied Psychology, 87, 698-714, doi: 10.1037/0021-9010.87.4.698.

Erdogan, B., \& Enders, J., 2012,Support From the Top : Supervisors Perceived Organizational Support as a Moderator of Leader - Member Exchange to Satisfaction and Performance Relationships, Journal of Applied Psychology, 92(2), 321-330

Faris Ihsan, 2014,Reformasi Budaya Kerja Pada Birokrasi Pemerintah. Artikel pada Website BKD dan Diklat Provinsi NTB.Http://Bkddiklat.Ntbprov.Go.Id/Wp Content/Uploads/2014/09/ReformasiBudaya-Kerja-Pada-BirokrasiPemerintah.Pdf

Ghozali, Imam, 2006,Aplikasi Analisis Multivariate Dengan Program SPSS, Cetakan Keempat, Semarang, Badan Penerbit Universitas Diponegoro

Handoko, Hani T., 2011,Manajemen Personalia dan Sumber Daya Manusia, BPFE, Edisi Kedua, Cetakan Kesebelas, Yogyakarta, Andi

Hasibuan, S. Malayu, 2008,Manajemen Sumber Daya Manusia, Jakarta, Bumi Aksara

Hutchinson, S, 2010, Perceived Organizational Support, Journal of Applied Psychology, Vol. 71, pp. 500507

Humaidi, Edi, 2006, Faktor- faktor yang Berpengaruh dalam Produktivitas Kerja Karyawan, http://husanah.staff.umm.ac.id/files/2 010/03/MAKALAH-final.pdf diunduh 06 Juli 2010.

Komaruddin, 2012,Manajemen Pengawasan Kualitas Terpadu Suatu Pengantar, Jakarta, Rajawali Press

Mangkunegara, Anwar Prabu, 2011, Evaluasi Kinerja Sumber Daya Manusia, Bandung, Remaja Rosdakarya

Mangkuprawira, Sjafri Tb., 2009, Bisnis, Manajemen, dan Sumberdaya Manusia, Bogor, IPB Press

Mary, Shelly, 2012,Perceived Organizational Support, Job Satisfaction and Employee Performance: An Chinese Empirical Study, Journal Service Science and Management, Vol. 3, (2010), pp 257- 264

Meyer, J. P. and Allen, N. J., 1997,Commitment to Organizations and Occupations: Extension and Test of a Three-Component Conceptualization, Journal of Applied Psychology, Vol. 78, No. 4, 538-551

Nawawi, Hadari, 2013,Kepemimpinan Mengefektifkan Organisasi, Yogyakarta, Gajahmada University Press

Ndraha, Taliziduhu, 2013,Budaya Organisasi, Jakarta, Rineka Cipta

Notoadmojo, Soekidjo, 2015, Metode Penelitian, Jakarta, Rineka Cipta

O'Reilly, A., 2009,Measuring Person-Job Fit with A Profile-Comparison Process, Journal of Applied Psychology, 75(6): 648-657

Pattipawae, Dezonda R., 2011,Penerapan Nilai - Nilai Dasar Budaya Kerja Dan Prinsip-Prinsip Organisasi Budaya Kerja Pemerintah Dengan Baik Dan Benar, Jurnal Sasi Vol. 17 No.3

Puspita, Dewi Rina, 2011,Menjaga dan Melindungi Budaya Kerja, Jakarta, Yudhistira

Rastogi, 2014,Budaya Kerja Etnik Dalam Kalangan Kakitangan Awam Di Pihak Berkuasa Tempatan Pasaman Barat, Wilayah Sumatera Barat, Indonesia, Disertasi Doktor Falsafah. Universiti Utara Malaysia, 
Robbins, P. Stephens, 2009,Organizational Behaviour, Tenth Edition (Perilaku Organisasi Ke Sepuluh), Jakarta, Salemba Empat

Robbins, Stephen P. And Coulter, Marry, 2010,Management, New Jersey, Pearson Education Inc.

Schraeder, Richard G., dkk, 2005,The Impact of Varios Factors on the Personality, Job Satisfaction and Turn Over Intention of Profesional Accountants, Managerial Auditing Journal, Vol. 16 No.4 pp 234245

Schein, Edgar H., 2014,Organizational Culture and Leadership, San Francisco, Josey-Bass Publishers

Sedarmayanti, 2008, Sumber Daya Manusia dan Produktifitas Kerja, Bandung, Mandar Maju

Siagian, Sondang P., 2012, Teori Produktifitas Kerja dan Aplikasinya, Jakarta, Rineka Cipta

Simamora, Henry, 2006, Manajemen Sumber Daya Manusia, Edisi 3, Yogyakarta, STIE YKPN

Sinungan, Muchdarsyah, 2009, Produktivitas Kerja; Apa dan Bagaimana, Jakarta, Bumi Aksara

Sopiah, 2008,Perilaku Organisasional, Yogyakarta, Andi Offset

Stefanus, Hadi Darmadji dan Rachmat, 2007, Sumber Daya Manusia dan Produktifitas Kerja, Yogyakarta, BPFE

Sugiyono 2012, Metode Penelitian Kuantitatif Kualitatif dan R\&D, Bandung, Alfabeta

Sutrisno, Edi, 2010,Manajemen Sumber Daya Manusia, Jakarta, Kencana Prenada Media Group

Suwanto dan Priansa, Donni Juni, 2011, Manajemen SDM dan Organisasi Publik dan Bisnis, Bandung, Alfabeta

Zurnali, Cut, 2010, Learning Organization, Competency, Organizational Commitment and Customer Orientation; Knowledge Worker, Bandung, Unpad Press

Zulkfili T, Paranoan, dan Achmad Djumali, 2014,Hubungan Budaya Kerja Dengan Komitmen Pegawai Negeri Sipil Di lingkungan Rumah Sakit Daerah Atma Husada Mahakam, eJournal Administratiive Reform. 2(2)/2014: 1316-1327

\section{Peraturan Perundang-Undangan :}

Peraturan Menteri PAN dan RB Nomor 10 Tahun 2011 tentang Pedoman Pelaksanaan Program Manajemen Perubahan 